\title{
Keutamaan Bekerja (Berproduksi) dalam Islam
}

\author{
Sri Anafarhanah
}

Fakultas Dakwah dan Komunikasi IAIN Antasari

\begin{abstract}
Work is the main pillar in production. Working as a production factor has a great meaning. Since all the natural wealth is useless if it is not exploited by humans and processed by workers. Nature has provided untold wealth, but without human effort will all be retained. Islam encourages Muslims to produce and play a role in various forms of economic activity in the form of agriculture, plantation, fishery, industry, and trade. By working person will be able to produce goods and services, and by the way as it did the workers will earn money so that they can meet their needs and their families. In addition, the work (production) someone will be spared of action beg.
\end{abstract}

Keywords: work, production, need fulfillment.

Bekerja merupakan sendi utama dalam produksi. Bekerja sebagai faktor produksi mempunyai arti yang besar. Karena semua kekayaan alam tidak berguna bila tidak dieksploitasi oleh manusia dan diolah oleh buruh (pekerja). Alam telah memberikan kekayaan yang tidak terhitung, tetapi tanpa usaha manusia semua akan tetap tersimpan. Islam menganjurkan umatnya untuk memproduksi dan berperan dalam berbagai bentuk aktifitas ekonomi baik berupa pertanian, perkebunan, perikanan, perindustrian, dan perdagangan. Dengan bekerja seseorang akan mampu menghasilkan barang dan jasa, dan dengan jalan seperti itu pula para pekerja akan mendapatkan penghasilan sehingga dapat memenuhi kebutuhan hidupnya serta keluarganya. Selain itu, dengan bekerja (berproduksi) seseorang akan terhindar dari tindakan meminta-minta.

Kata kunci: bekerja, produksi, pemenuhan kebutuhan.

Para ahli ekonomi menetapkan bahwa produksi terjadi lewat peranan tiga unsur yang saling berkaitan yaitu alam, modal, dan bekerja. Yang dimaksud dengan alam (bumi) adalah segala kekayaan alam yang diciptakan Allah SWT agar bisa dimanfaatkan oleh manusia sebagai bekal yang mereka butuhkan. Modal adalah aset, baik berbentuk alat ataupun bangunan yang semuanya merupakan hasil kerja manusia. Sedangkan yang dimaksud dengan bekerja adalah segala usaha maksimal yang dilakukan manusia, baik lewat gerak anggota tubuh ataupun akal untuk menambah kekayaan, baik dilakukan secara perseorangan ataupun secara kolektif, baik untuk pribadi ataupun untuk orang lain (dengan menerima gaji). ${ }^{1}$

1 Yusuf Qardhawi, Norma dan Etika Ekonomi Islam, (Jakarta: Gema Insani Press, 1997), hal. 104

Email penulis: srianafarhanah@yahoo.co.id

Alhadharah Jurnal Ilmu Dakwah Vol. 15 No. 30, Juli-Desember 2016, 29-38 


\section{Hadits Tentang Keutamaan Bekerja}

Dalam tulisan ini penulis akan mentakhrij sebuah hadits yang penulis kutip dari hadits Shahih Bukhari yang menjelaskan tentang keutamaan bekerja. ${ }^{2}$

a. Hadits Utama

Hadits yang diriwayatkan oleh Imam Bukhari

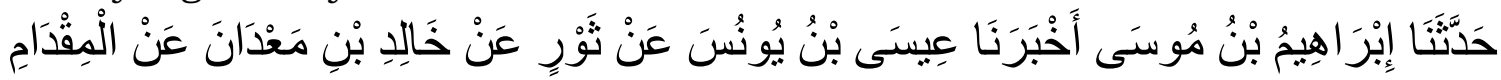
رَضِيَ اللَّهُ عَنْنُ

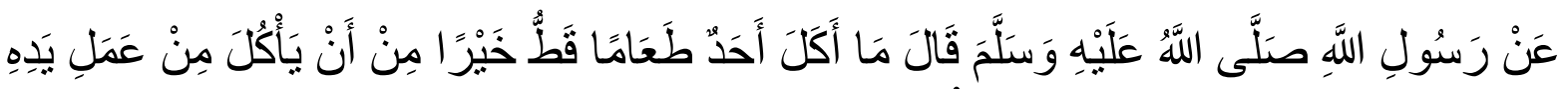

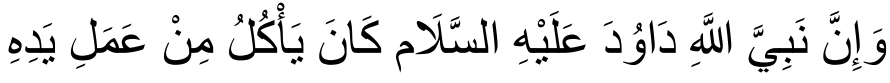

"Telah menceritakan kepada kami [Ibrahim bin Musa] telah mengabarkan kepada kami ['Isa bin Yunus] dari [Tsaur] dari [Khalid bin Ma'dan] dari [Al Miqdam radliallahu 'anhu] dari Rasulullah shallallahu 'alaihi wasallam bersabda: "Tidak ada seorang yang memakan satu makananpun yang lebih baik dari makanan hasil usaha tangannya sendiri. Dan sesungguhnya Nabi Allah Daud AS memakan makanan dari hasil usahanya sendiri"."3

b. Hadits Pembanding

Adapun hadits pembanding dari hadits diatas yakni :4

- Musnad Ahmad, no hadits 23809 Kitab : Sisa Musnad Sahabat Anshar

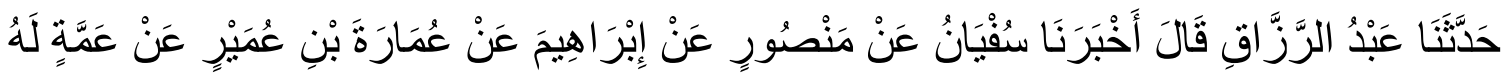

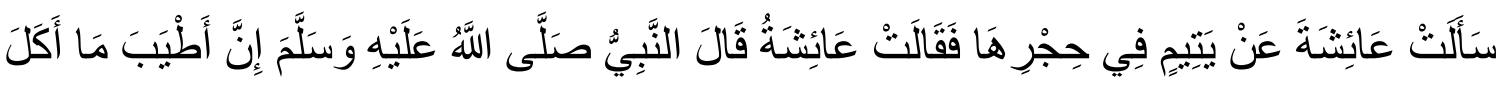

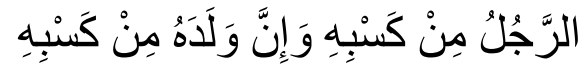

"Telah menceritakan kepada kami [Abdurrazzaq], dia berkata; Telah mengabarkan kepada kami [Sufyan] dari [Manshur] dari [Ibrahim] dari [Umaroh bin Umair] dari [bibinya] bertanya kepada [Aisyah] tentang anak yatim yang ada dipangkuannya, Aisyah berkata; Rasulullah Shallallahu'alaihiwasallam pernah bersabda: "Yang paling baik dimakan oleh seseorang adalah dari hasil usahanya, dan anak laki-laki adalah juga dari hasil usahanya."

\footnotetext{
${ }^{2}$ Kitab Shahih Bukhari Juz 2 kitab Tentang Jual Beli no hadits 2072, hal. 12

${ }^{3}$ http://www.lidwa.com//app/ diakses tanggal 25 Juli 2016

${ }_{4}^{4}$ Hadits pembanding diatas, penulis kutip dari http://www.lidwa.com//app/ diakses tanggal 25 Juli 2016
} 
c. Pohon Sanad

Rasulullah SAW

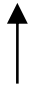

Al-Miqdam bin Ma'diy

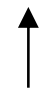

Khalid bin Ma'dan bin Abi Karb

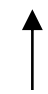

Tsaur bin Yazid bin Ziyad

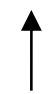

Isa bin Yunus bin Abi Ishaq<smiles>[13CH3]</smiles>

Ibrahim bin Musa bin Yazid bin Zadzan

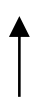

Imam Bukhari
Rasulullah SAW

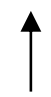

Aisyah binti Abi Bakar As-Shiddiq

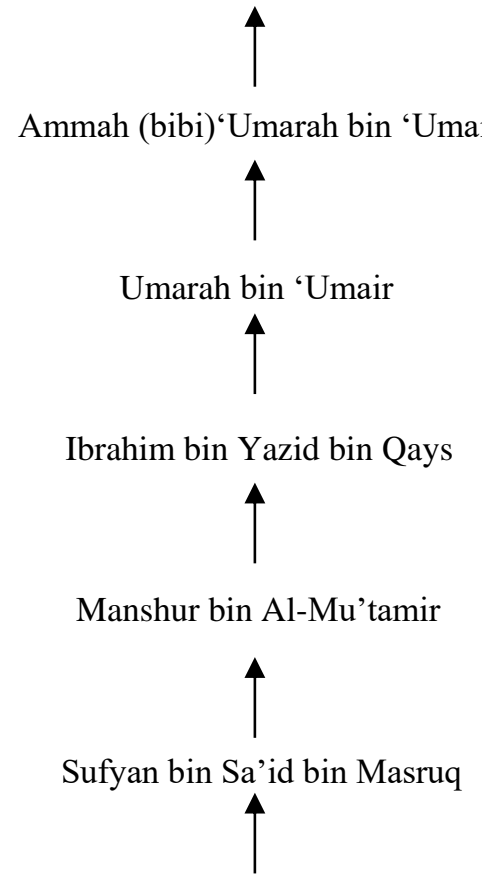

Abdur Razzaq bin Hammam bin Naff

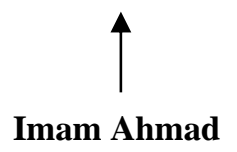

\section{Biografi Para Perawi Hadits}

1. Imam Bukhari

Imam Bukhari nama lengkapnya Abu 'Abdullah Muhammad ibn Isma'il ibn Ibrahim ibn al-Mughirah ibn Bardizbah al-Ja'fi al-Bukhari. ${ }^{5}$ Lahir di kota Bukhari

\footnotetext{
${ }^{5}$ Endang Soetari, Ilmu Hadits, (Bandung: Amal Bakti Press, 1997), hal. 302
} 
pada tanggal 13 Syawwal 194 H/810 M dan wafat di Samarkand pada malam 'Idul Fitri tahun $256 \mathrm{H}=31$ Agustus $870 \mathrm{M}$.

Imam Bukhari belajar hadits dari ulama hadits termasyhur, di antaranya: Malik ibn Anas, Hammad ibn Zayd, Ibn Mubarak, 'Ali ibn al-Madini, Ahmad ibn Hanbal, Yahya ibn Ma'in, Muhammad ibn Yusuf al-Fiyabi, dan Ibn Rawaih.

Sebelum mencapai usia enam belas tahun, Imam Bukhari telah berhasil menghafalkan beberapa kitab hadits, di antaranya karangan Ibnu al-Mubarak dan Waki'. Ia hapal 100.00 hadits shahih dan 200.00 hadits yang tidak shahih. Beliau tidak hanya menghapalkan matan hadits dan buku ulama terdahulu, tetapi ia juga mengenal betul biografi para periwayat yang mengambil bagian dan penukilan sejumlah hadits, data tanggal lahir, meninggal, dan tempat lahir.

Kekuatan ilmu dan hafalan Imam Bukhari, maka para guru, kawan, murid, dan generasi sesudahnya memujinya. Di antara mereka yang memuji Imam Bukhari adalah Abu Bakar Ibn Khuzaimah, al-Hakim, dan Ibnu Hajar al-Asqalani. Abu Bakar ibn Khuzaimah mengatakan: "di kolong langit ini tidak ada ahli hadits yang melebihi Imam Bukhari." Al-Hakim menceritakan dengan sanad lengkap, bahwa Muslim yang menulis kitab shahih Muslim datang dan mencium antara kedua mata Imam Bukhari dan berkata: "Guru, biarkan aku mencium kedua kakimu. Engkaulah imam ahli hadits dan dokter penyakit hadits." Sementara Ibnu Hajar al-'Asqalani mengatakan bahwa: "Seandainya pintu pujian dan sanjungan masih terbuka bagi generasi sesudahnya, niscaya kertas dan nafas akan habis, karena ia bagaikan laut yang tidak berpantai."

Di antara guru Imam Bukhari adalah Ali ibn al-Madini, Ahmad ibn Hanbal, Yahya ibn Ma'in, dan ibn Rawaih. Adapun murid beliau di bidang hadits banyak sekali sehingga ada yang mengatakan murid Imam Bukhari sebanyak 90.000 orang. Di antara muridnya adalah Muslim al-Hajjaj, al-Turmuzi, Ibnu Khuzaimah, Ibnu Abu Daud, dan ibn Yusuf al-Fiyabi. ${ }^{6}$

2. Ibrahim bin Musa bin Yazid bin Zadzan

$\begin{array}{ll}\text { Kalangan } & \text { : Tabi'ul Atba' kalangan tua } \\ \text { Kuniya } & : \text { Abu Ishaq } \\ \text { Negeri Hidup } & \text { : Rayi } \\ \text { Tahun Wafat } & : 220 \mathrm{H} \\ \text { Pendapat Kritikus } & \text { : Ad-Dzahabi : Al-Hafidz, An-Nasa'i : Tsiqah, Ibnu Hajar Al- } \\ & \text { Asqalani: Tsiqah Hafidz }\end{array}$

3. Isa bin Yunus bin Abi Ishaq

Kalangan $\quad$ : Tabi'ut tabi'in kalangan pertengahan

\footnotetext{
${ }^{6}$ http://lidwa.com/2011/biografi-imam-bukhari/diakses tanggal 25 Juli 2016
} 


\begin{tabular}{|c|c|}
\hline Kuniya & : Abnu Amru' \\
\hline Negeri Hidup & : Kufah \\
\hline Tahun Wafat & $: 187 \mathrm{H}$ \\
\hline Pendapat Kritikus & $\begin{array}{l}\text { : Abu Hatim : Tsiqah, Abu Zur'ah : Hafidz, Ad Dzahabi : } \\
\text { Ahadul A'lam fil hifdzi wal “ibadah”, Ahmad bin Hambal : } \\
\text { Tsiqah, An-Nasa'i : Tsiqah, Ibnu Hajar Al-Asqalani : Tsiqah } \\
\text { Ma'mun, Ibnu Hibban : disebutkan dalam Ats'tsiqah, Ibnu } \\
\text { Madini : Tsiqah, yahya bin Ma'in : Tsiqah }\end{array}$ \\
\hline
\end{tabular}

4. Tsaur bin Yazid bin Ziyad

$\begin{array}{ll}\text { Kalangan } & : \text { Tabi'ut tabi'in kalangan tua } \\ \text { Kuniya } & : \text { Abu Khalid } \\ \text { Negeri Hidup } & : \text { Syam } \\ \text { Tahun Wafat } & : 150 \mathrm{H} \\ \text { Pendapat Kritikus } & : \text { Ahmad bin Hambal : laisa bihi ba's, Ibnu Ishaq : Tsiqah, } \\ & \end{array}$

5. Khalid bin Ma'dan bin Abi Karb

Kalangan $\quad$ : Tabi'in kalangan pertengahan

Kuniya $\quad$ : Abu 'Abdullah

Negeri Hidup : Syam

Tahun Wafat $\quad: 104 \mathrm{H}$

Pendapat Kritikus : Al-'Ajli : Tabi'i tsiqah, An-Nasa'i : Tsiqah, Ibnu Hibban : disebutkan dalam Ats Tsiqah, Muhammad bin Sa'd : Tsiqah, Ya'kub Ibnu Syaibah : Tsiqah

6. Al-Miqdam bin Ma'diy

$\begin{array}{ll}\text { Kalangan } & : \text { Sahabat } \\ \text { Kuniya } & : \text { Abu Karimah } \\ \text { Negeri Hidup } & : \text { Syam } \\ \text { Tahun Wafat } & : 87 \mathrm{H}\end{array}$


Pendapat Kritikus : Sahabat ${ }^{7}$

\section{Sanad dan Matan Hadits}

1) Analisis Sanad Hadits

Sanad menurut bahasa berarti "sandaran". Menurut istilah ahli hadits, matan adalah jalan yang menyampaikan kita kepada matan hadits. ${ }^{8}$ Dalam hadits ini, penulis menganalisis sanad hadits dengan melihat dari biografi para perawai dengan menyimpulkan bahwa, semua perawi hadits di atas tsiqah, bersambung (muttasil) dan sanadnya juga sampai kepada nabi (marfu).

2) Analisis Matan Hadits

Menurut istilah hadits ${ }^{9}$, yang dimaksud dengan matan hadits adalah pembicaraan (kalam) atau materi berita yang diover oleh perawi yang berada di akhir sanad (sahabat).

Dalam periwayatan matan hadits dapat dilakukan dengan dua cara, yaitu riwayat bi al-lafdzi dan riwayat bi al-ma;na. riwayat bi al-lafdzi adalah menyampaikan kembali kata-kata nabi dengan redaksi kalimat yang sama dengan apa yang disabdakan Nabi. Dengan periwayatan bi al-lafdzi, maka tidak ada perbedaan antara seorang perawi dengan perawi lainnya dalam menyampaikan hadits Nabi. Akan tetapi, dalam kenyataannya, banyak sekali hadits yang ada di dalam kitab-kitab karya mereka ditulis dengan redaksi yang sedikit banyak berbeda redaksi kalimatnya, meskipun makna yang dikandungnya sama. Hal ini menunjukkan bahwa para perawi itu tidak meriwayatkan hadits dengan cara riwayat bi al-lafdzi melainkan dengan cara yang disebut riwayat bi al-ma'na.

Hadits tentang keutamaan bekerja diatas, selain terdapat dalam Shahih Bukhari, juga terdapat Musnad Imam Ahmad bin Hambal. Adapun hadits ini diriwayatkan oleh Al-Miqdam bin Ma'diy dan Aisyah binti Abi Bakar AshShiddiq dengan periwayatan yang berbeda, lafadz yang berbeda namun mengandung makna yang sama yakni tentang keutamaan bekerja dengan hasil usaha sendiri.

Melihat sanad dan matan hadits tersebut, penulis memberikan kesimpulan bahwa hadits di atas berkualitas shahih dikarenakan telah memenuhi syaratsyarat hadits shahih yaitu:

a. Mempunyai sanad yang bersambung (muttasil)

b. Para perawinya 'adil

c. Para perawinya dhabith

d. Tidak mengandung unsur-unsur syadz

\footnotetext{
${ }^{7}$ http://www.lidwa.com//app/ diakses tanggal 25 Juli 2016

8 T.M. Hasbi Ash-Shiddieqy, Sejarah dan Pengantar Ilmu Hadits, (Jakarta: Bulan Bintang, 1980), hal. 192

${ }^{9}$ Khan, Majid. dkk. Ulumul Hadits. Jakarta: Pusat Studi Wanita (PSW) UIN Jakarta, 2005
} 
e. Tidak mengandung kecacatan ('illat) yang dapat merusak keabsahan sebuah hadits, seperti menyambungkan hadits-hadits yang jelas terputus sanadnya (washu munqathi), me-marfu'-kan yang mauquf (raf'u mauquf) dan memursal-kan yang maushul (irsal al-maushul).

\section{Pembahasan}

\section{Pemaknaan Hadits}

Hadits diatas menjelaskan tentang keutamaan bekerja. Hadits ini menunjukkan bahwa bekerja merupakan perbuatan yang sangat mulia dalam ajaran Islam. Dalam hadits ini penulis akan menguraikan makna dari kutipan hadits di atas yakni :

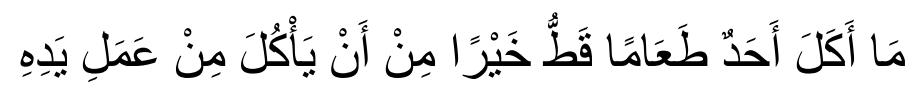

(Tidak ada seorang yang memakan satu makananpun yang lebih baik dari makanan hasil usaha tangannya sendiri)

Dalam kalimat di atas ada penekanan terhadap kata مِنْ عَمَل يَّه yang artinya "dari tangannya sendiri". Adapun Pemaknaan dari kutipan hadits tersebut adalah "bekerja dengan hasil usaha sendiri jauh lebih mulia dibandingkan mengharap dari orang lain (meminta-minta)". Islam sangat menghargai orang yang bekerja dengan tangannya sendiri. Rasulullah SAW memberikan pelajaran menarik tentang pentingnya bekerja. Dalam Islam bekerja bukan sekadar memenuhi kebutuhan perut, tapi juga untuk memelihara harga diri dan martabat kemanusiaan yang seharusnya dijunjung tinggi. Karenanya, bekerja dalam Islam menempati posisi yang teramat mulia.

Ketika orang yang bekerja, berusaha untuk mendapatkan penghasilan dengan tangannya sendiri baik untuk membiayai kebutuhannya sendiri ataupun kebutuhan anak dan isteri (jika sudah berkeluarga), dalam Islam orang seperti ini dikategorikan jihad fi sabilillah. Dengan demikian Islam memberikan apresiasi yang sangat tinggi bagi mereka yang mau berusaha dengan sekuat tenaga dalam mencari nafkah (penghasilan). ${ }^{10}$

Bekerja di dalam Islam adalah suatu kewajiban bagi mereka yang mampu. Tidak dibenarkan bagi seorang muslim berpangku tangan dengan alasan "mengkhususkan waktu untuk beribadah" atau bertawakkal kepada Allah. Langit tidak pernah menurunkan emas ataupun perak. Tidak dibenarkan pula bagi seorang muslim bersandar pada bantuan orang lain sedangkan ia mampu dan memiliki kemampuan. ${ }^{11}$

Adapun hadits yang semakna dengan hadits di atas yakni :

\footnotetext{
${ }^{10}$ http://frijal.com/anjuran-bekerja-dalam-islam/ diakses tanggal 25 Juli 2016

11 Yusuf Qardhawi, Norma dan Etika Ekonomi Islam, (Jakarta: Gema Insani Press, 1997), hal.103
} 


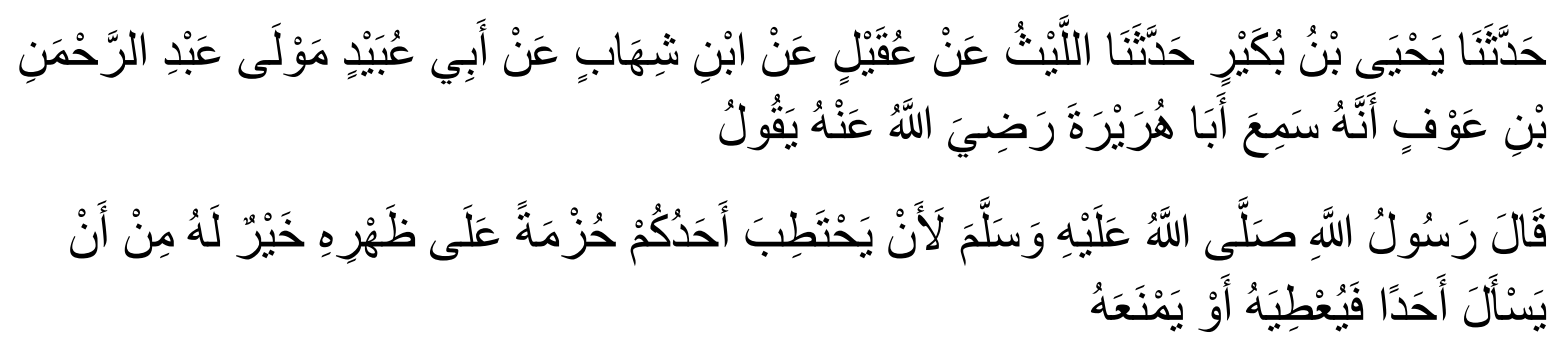

"Telah menceritakan kepada kami [Yahya bin Bukair] telah menceritakan kepada kami [Al Laits] dari ['Uqail] dari [Ibnu Syihab] dari [Abu 'Ubaid] sahayanya 'Abdurrahman bin 'Auf bahwa dia mendengar [Abu Hurairah radliallahu 'anhu] berkata, Rasulullah shallallahu 'alaihi wasallam bersabda: "Sungguh, seorang dari kalian yang memanggul kayu bakar dan dibawa dengan punggungnya lebih baik baginya daripada dia meminta kepada orang lain, baik orang lain itu memberinya atau menolaknya".(HR. Bukhari)

Kerja juga berkait dengan martabat manusia. Seorang yang telah bekerja dan bersungguhsungguh dalam pekerjaannya akan bertambah martabat dan kemuliannya. Sebaliknya, orang yang tidak bekerja alias menganggur, selain kehilangan martabat dan harga diri di hadapan dirinya sendiri, juga di hadapan orang lain. Jatuhnya harkat dan harga diri akan menjerumuskan manusia pada perbuatan hina. Tindakan mengemis, merupakan kehinaan, baik di sisi manusia maupun di sisi Allah SWT.

Akan tetapi perlu diingat bahwa yang dimaksud dalam hadits-hadits di atas adalah orang yang bekerja sesuai dengan ajaran Islam. Bekerja pada jalur halal dan bukan bekerja dengan pekerjaan yang diharamkan oleh Allah SWT.

\section{Bekerja dalam Perspektif Ekonomi Islam}

Ilmu tidak bermanfaat kalau tidak dipraktekkan dengan bekerja. Bekerja dibutuhkan bukan hanya sekali waktu, tapi terus-menerus. Bekerja dibutuhkan untuk menghasilkan (memproduksi) sesuatu yang terbaik dan untuk mencapai karunia Allah SWT.

Bekerja sebagai faktor produksi mempunyai arti yang besar. Karena semua kekayaan alam tidak berguna bila tidak dieksploitasi oleh manusia dan diolah oleh buruh (pekerja). Alam telah memberikan kekayaan yang tidak terhitung, tetapi tanpa usaha manusia semua akan tetap tersimpan. Oleh karena itu, disamping adanya sumber daya alam, juga harus ada rakyat yang mau bekerja sungguhsungguh, tekun dan bijaksana agar mampu menggali sumber alam untuk kepentingannya. Kitab suci Al-Qur'an memandang betapa pentingnya produksi kekayaan negara, dengan memberi penekanan yang lebih terhadap tenaga manusia. ${ }^{12}$ Hal ini dapat dilihat dari firman Allah SWT dalam surah An-Najm ayat 39 :

12 Afzalur Rahman, Doktrin Ekonomi Islam Jilid 1, (Yogyakarta: Dana Bhakti Wakaf, 1995), hal. 249 


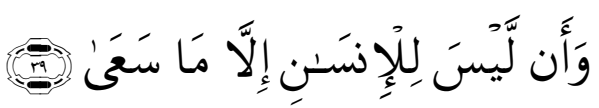

39. Dan bahwasanya seorang manusia tiada memperoleh selain apa yang Telah diusahakannya.

Ekonomi Islam sangat menganjurkan dilaksanakannya aktivitas produksi dan mengembangkannya, baik dari segi kuantitas maupun kualitas. Ekonomi Islam tidak rela jika tenaga manusia atau komoditi telantar begitu saja. Islam menghendaki semua tenaga dikerahkan untuk meningkatkan produktivitas lewat itqan (ketekunan) yang diridhai Allah SWT atau ihsan yang diwajbkan Allah atas segala sesuatu. ${ }^{13}$ Oleh sebab itu Islam menganjurkan umatnya bekerja untuk memproduksi dan berperan dalam berbagai bentuk aktivitas ekonomi seperti pertanian, perkebunan, perikanan, perindustrian, dan perdagangan. Disamping itu, tujuan diwajibkannya bekerja adalah untuk :

1) Untuk mencukupi kebutuhan hidup

2) Untuk kemaslahatan keluarga

3) Untuk kemaslahatan masyarakat

4) Mengatasi pengangguran

5) Bekerja untuk memakmurkan bumi, dan berbagai tujuan lainnya.

\section{Kesimpulan}

Hadits yang diriwayatkan oleh Imam Bukhari menjelaskan mengenai betapa pentingnya bekerja. Karena dengan bekerja kita mampu menghasilkan sesuatu yang bermanfaat bagi kehidupan dan lingkungan sekitar kita serta dapat mengurangi tingkat pengangguran dan kemiskinan. Hadits ini juga diperkuat dengan dalil-dalil Al-Qur'an. Dengan adanya hadits dan dalil Al-Qur'an ini, maka kewajiban tersebut semakin kuat, sehingga sudah seharusnya kita berhenti untuk bermalas-malasan dan mengharap sesuatu yang datang dari orang lain (meminta-minta) karena hal itu tidak akan membawa kebaikan bagi diri kita dan lingkungan.

${ }^{13}$ Yusuf Qardhawi, Norma dan Etika Ekonomi Islam, (Jakarta: Gema Insani Press, 1997), hal. 123 


\section{Referensi}

Ash-Shiddieqy, T.M. Hasbi. 1980. Sejarah dan Pengantar Ilmu Hadits. Jakarta: Bulan Bintang

Khan, Majid. dkk. 2005. Ulumul Hadits. Jakarta: Pusat Studi Wanita (PSW) UIN Jakarta

Kitab Shahih Bukhari Juz 2 kitab Tentang Jual Beli no hadits 2072

Rahman, Afzalur. 1995. Doktrin Ekonomi Islam Jilid 1. Yogyakarta: Dana Bhakti Wakaf

Soetari, Endang. 1997. Ilmu Hadits. Bandung: Amal Bakti Press

Qardhawi, Yusuf. 1997. Norma dan Etika Ekonomi Islam. Jakarta: Gema Insani Press

http:/ / frijal.com/anjuran-bekerja-dalam-islam/ diakses tanggal 25 Juli 2016 http://lidwa.com/2011/biografi-imam-bukhari/diakses tanggal 25 Juli 2016 http://www.lidwa.com//app/ diakses tanggal 25 Juli 2016 